\title{
Ons is Boesmans: commentary on the naming of Bushmen in the southern Kalahari
}

\author{
William F. Ellis
}

\begin{abstract}
:
This paper examines academic debates about the nomenclature of the San in light of recent ethnographic data. Academic debates centre around two aspects: the apparent complicity of the term "bushman" in construing the San as lower on the hierarchy of race and class; and the construction of the San as being in close contact with animals and nature. Academics have sought to resolve this dilemma of complicity by adopting selfreferential terms, which would allow them to overcome the effacement of cultural and linguistic variation. Critically, the paper argues that this turn to self-referential terms is problematic in the case of the $\neq$ Khomani San of the southern Kalahari because the San themselves claim "bushman" as their identity. The analysis suggests that the $\neq$ Khomani San claim this name for themselves in a context of developmental needs. Thus, $\neq$ Khomani San chose the name "Bushman" for themselves because it can be commoditised.
\end{abstract}

In desperation to endow the colonized with an essence and enshrine them in a fossil, the colonizer can confine them in a name. The colonized will later appropriate it with all the strength at their command - and will also have appropriated all its deadly effects. Thanks to this name given by the settler, the native will become a fragment of the real, an objective thing, matter. The world of names and worlds of things will then be a single reality, and the settler able to make a representation of the colonized. (Mbembe 2001, 187)

\section{Introduction}

In 1995 , the $\neq$ Khomani San of the southern Kalahari lodged a claim for land located inside the Kalahari Gemsbok National Park. As part of a complex and fairly all-embracing restitution package, the $\neq$ Khomani San were granted more than 68 ooo hectares of land, financial compensation as well various rights of access to the Park. ${ }^{i}$ According to the restitution agreement, the compensation was handed over to the $\neq$ Khomani gradually over the period from 1999 to 2003. Despite the delight at the return of "their" land, the \# Khomani soon realised that the community under the name of which they had submitted the land claim was not as coherent and concrete a unit as they had assumed. Instead, it revealed itself as a fractious collective. Some members of the collective had not even known each other before the claim was submitted.

The cracks in the unity of the $\neq$ Khomani community arose around issues of who could legitimately and authentically claim to belong to the community. In this debate, the terms "Bushman" and "Boesman" came to play a critical role. Academic discourse dating back as 
far as the 1950s declared the terms "Bushman" and its Afrikaans counterpart "Boesman" to be racist, derogatory and even sexist and called for their removal from general discourse. Nearly 60 years later, however, San people living in the southern Kalahari refer to themselves by these terms. Not only are the terms in common use, but some $\neq$ Khomani embrace them proudly, declaring: "Ons is boesmans" [we are Bushmen].

The embracing of terms that had been rejected by academics can be understood in terms of what elsewhere has been called the "authenticity construct," namely a contest over authenticity or "narratives of authenticity" (see Ellis 2010, 2012, 2014). According to Guenther (1995, 111), the "authenticity construct" is composed of "a stereotyped, racialcultural iconography and representations of the San, ideas that 'standardised' their culture, and a general prescription of this 'construct' as appropriate to proposals for development." Stereotypic ideas of what it means to be San guided the visions for economic welfare and proposals for development of the $\neq$ Khomani San community and the $\neq$ Khomani were expected to act within this framework of San-ness. ii The "authenticity construct" is that index that is constructed from the jumble of ideas and materials which can be referenced by whosoever needs to show what a real bushman (lower case intentionally used, see Rassool and Hayes 2002; Ellis 2014) ${ }^{\text {iii }}$ is. Among the many practices and ideologies that make up these standardising and authenticating practices of the authenticity construct are the acts of naming and ascription of terms to supposed ethnic entities. The aim of this particular paper is to probe this acceptable San norm (Ellis 2010) or, as Guenther puts it, the authenticity construct, in relation to the diverse practices that assign and determine San nomenclatures.

The paper does not wish to discuss Guenther's authenticity construct itself in any detail. Rather, it examines one specific "construct," namely the choice of nomenclatures by diverse $\neq$ Khomani interest groups. The paper argues that various $\neq$ Khomani interest groups developed names and labels for themselves by using ethnonyms, glottonyms and self-referents. Their search for appropriate names is, critically, about being able to lay a claim to the disputed land as their own, in sufficiently authentic a manner.

It is not the goal of this paper to suggest a new or novel nomenclature, nor to suggest that terms proposed by $\neq$ Khomani interest groups should be accepted. The intention is rather to illuminate a dynamic process of name selection that reflects a localised set of responses to political, socio-economic, policy and other conditions that prevail and exert influence on the lives of people. The process of a community selecting a name for itself does not occur in a vacuum: it takes place within a context and situatedness.

The question posed by this paper is: why should the naming practices take the form that they do? The paper analyses the question along two strands. First, it reads the concern with nomenclature in light of current ethnographic data. Using ethnographic data is critical as it permits a view of the fact that, despite the academic critique, San are choosing to be located in nature from where they want to make their living. The ethnographic data suggests that, once the land claim is settled, bushman-ness will be put to work in an interplay of the representational and the developmental. The aspirations of certain bushmen is to commoditise culture and make it "work," that is to do labour: to let 
it provide food, income, housing, healthcare and services such as water, toilets and electricity.

\section{"Confined to a name"}

The epigram by Mbembe that opens this paper neatly captures the process of naming and its effects in especially the colonised territories of the world when it argues that the colonised have been "confined to a name." The "confinement" turns the gaze away from humans as objects of analysis and traps knowledge of them in representations; in short, names are crucial in creating simulacra. Moreover, "confinement" conveniently provides an empty category to be filled with materials and references. Once a name and its associated category become established, it is ready to be populated with various racial and ethnological referents, signs and even materials. The word "bushman," for example, instantly evokes a veritable catalogue of signs, such as bows and poison arrows, the loincloth, ostrich eggshell beads, click languages and specific racial features. These indexical materials and signs are not lost in the present; rather, they are sublated into whatever San people are currently doing. I am understanding sublation according to Hegel ([1807] 1910) as the principle of something that is being cancelled out without being destroyed. A new form emerges that is at once still what it was before and at the same time novel.

Western popular theories of change and social constructionism cannot accommodate sublation in their views of the San. Many of the non-San people, and here I refer to all those individuals who are not known as San nor have they volunteered an identity as San, encountered in the southern Kalahari during fieldwork ${ }^{\text {iv }}$ thought of the San as either trapped in the past or as corrupted by historical forces. Thus the San are forced to be either "bushmen" or "not bushmen." What is more critical, however, is that some groups of $\neq$ Khomani think of being bushman in similarly restricted ways, unable to incorporate the phenomenon of sublation into their definitions of what makes up an authentic bushman. The poorest among the $\neq$ Khomani San are the most fervent advocates of the view that the claimants in the land claim can be grouped into the westerse [westernised San] and the tradisie [traditional San]. In contrast, the San who are regarded as westernised, who are also often those who are better off in the community, embraced the possibility of a sublated iden-tity; in fact, their own San-ness depended on this sublation. It is telling to note here that those San who accept the sublated perspective of identity also use the term "San" to refer to themselves. Conversely, those San who cannot accept sublation as playing a role in identity building tend to use the term "Boesman." The contests of authenticity, it seems, centre on the indices and materials. The construct not only begins with this name but persistently returns to this name: it is that index that materials are attached to. The discussion now turns to an analysis of the names and terms that have been assigned to, and some even claimed by, the San.

Over the centuries of contact with Europeans and other groups, such as Nguni-speaking farmers and slaves of diverse national origins brought to the Cape, the San of southern Africa have been identified by numerous different terms. Diverse ethnonyms, or appellations applied to ethnic groups, were used. They can be understood in terms of a typology of ethnonyms that has been developed by academics. Some ethnonyms used for the San have been xenonyms, names used to label "strange" or "foreign" groups. The 
names can be constructed from words taken from the ethnic group that is being described, thus an auto-xenonym, or can be ascribed, thus come from another language. Other ethnonyms denote the language spoken by the people in question, such as Nharo or $\mathrm{Ju} /$ 'hoansi, and are thus philological terms or glottonyms. Another number of ethnonyms applied to the San involve academic conventions or are the result of the attempt by researchers to find politically correct terms. "Bushmen," "San," the Afrikaans word "Boesman," the Nguni "Abathwa" and the Tswana "Basarwa" are some of the terms most commonly applied to the San. Each of them is used in different settings and can have both positive and negative connotations. For instance, the everyday Afrikaans "Boesman" or the colloquial English "Bushmen" denotes a person with a particular set of racial features that are not favoured by the dominant portion of society. This appellative is hardly ever used in a flattering or laudatory way. The terms also imply a hierarchical prescript, so that a person designated a Bushman is immediately placed on a lower level within commonly assumed social and cultural strata. And, while some prefer to see the San as Stone Age relics while others are yet to see them as equals in a relativist sense, it is useful to remember that these terms are "ideologically versatile" and appeal to actors across the political spectrum (see Douglas 1995). At the same time the terms are generic and homogenising: they lump people together regardless of any inter- and intra-group diversity. On the other side of the spectrum are self-referring terms, which are used to overcome the damage of past naming practices. The following surveys and briefly evaluates the principal terms that have been used.

The xenonym "Bushman" is undoubtedly the most frequently used designation when people speak about the San. It has its origin in the early years of Dutch colonisation of the Cape in the 17th century and derives from the Dutch bosjesman. According to Humphreys (1985), the term captures the idea that the San were seen by colonists as an elusive people who could only be glanced before they disappeared into the bushes (bosjes/bossies) again. Nienaber (1952) claims that the diminutive "bossies" was used because it denoted the indigenous shrubby fynbos. Academics in the 1950s decided to use the term "San," a philological term, instead of the derogatory "Bushman" (Morris 1992), which was considered racist, hierarchical, sexist and suffused with negative connotations (see Lee 1976; Gordon and Sholto-Douglas 2000; Guenther 1986). Despite the widespread use of "San" in academic and Western popular culture, the replacement of "Bushman" by the term "San" did not completely recuperate the image of the San. The attempt to recuperate the term would take on a different slant from the 1980 os onwards when the emergence of new linguistic and ethnographic information allowed a deeper understanding to develop of how San themselves thought about the word "San." Firstly, Wilmsen showed that the term "San" derived from the Khoekhoegowab word "sa" which means "to gather" (Wilmsen 1989). The verb "gather" indicates a livelihood that stands in contrast to the pastoral lifestyle of Africans who were living in their vicinity. Ethnographic work by Guenther (1986) illustrates that the Namibian San understood the term "San" as an insult. Additionally, Hitchcock and Biesele (2000) found that the respondents in their studies did not know the word "San" from their own language but that Nama speakers had used it in a pejorative manner towards them. A year later, however, the term was in common use among those who had claimed only a year earlier to have barely any knowledge of it (Hitchcock and Biesele 2003). Despite the fact that information about possible pejorative meanings carried by the word "San" had circulated among the general 
public, the term seems to be gaining credence particularly among those who are designated by it. The political transitions in southern Africa over the last two and a half decades have created the political space for pan-San activism. The common term used by civil society organisations (such as the South African San Council, the Kuru Development Trust or the First People of the Kalahari) is the term "San." "San" has, thus, become popular within the context of first people's activism.

"San" as referent, in both its origin and meanings, is intricately bound up in the collective ethnonym Khoisan. In fact, all indications are that "San" is a xenonym that the Dutch learnt from the Khoikhoi. To understand the term "San" fully, one needs to be clear on the usages and meanings of the word in the Khoekhoegowab linguistic and cultural context. In the Khoe language, the word "khoi" means men/people. When the Dutch enquired about self-referents used by the pastoralists they encountered in the 17th century, the term they were given by the indigenous people was Khoikhoi, meaning "people of people." In many southern African linguistic contexts, duplication has the effect of emphasising that something is genuine or real. Therefore, it can here be read to indicate "real people" (Nienaber 1990). One could also think of it in terms of an English phrase such as "a man's man" to signify a real man. The telling interpretation is when the word "khoi" is combined with "San," so that "Khoisan" would thus refer to a person who gathers (Wilmsen 1989). As pastoralists generally looked down upon the "gathering" lifestyle, being San thus means someone who has a lesser lifestyle. As a result, "San" does not have a positive meaning, even in its original linguistic context. Yet, regardless of these negative connotations, "San" is currently the most commonly used referent in academic, advocacy and political circles.

While it is sufficient for the purposes of this paper to disaggregate San from Khoisan, one further detail deserves to be mentioned here. The term "Khoisan" is now part of the South African popular and political discourse as a collective term for those who are descended from the Khoikhoi and the San. The term does not exclude or limit according to livelihood (that of pastoralism and foraging), but rather assumes a common ancestry and claims descent from an autochthonous group of the subcontinent (Bredekamp 1991, 71). Here the use of autochthony excludes Bantu-speaking farmers who arrived in the subcontinent a mere 2000 years ago and with whom the Khoisan intermarried.

So what might the verdict be on the two terms, "San" and "Bushman"? They are so complexly intertwined that it makes it nearly impossible to isolate one from the other (Douglas 1995; Voss 1990). Some theorists and scholars have argued that the use of terms with negative connotations might have some merit. Thus, Gordon and Sholto-Douglas (2000) suggest retaining the term "Bushman" because it highlights a long and valiant struggle against colonialism. The suggestion here is that the name "Bushman" can be recuperated and made to represent Bushman-ness as heroic. In contrast, Wilmsen cautioned that "[t]his historicity of nomenclature cannot be erased, neither by academic or vernacular valorisation of iconic images, no matter whether baptised with either positive or negative locutions" (Wilmsen 1996, 188).

Two further terms are invaluable in the studies of the portrayal of San people, though they are not well known outside of their cultural contexts: the terms "Abathwa" and 
"Basarwa." "Abathwa" is used throughout the Bantu-speaking world to refer specifically to people who practice a foraging mode of subsistence. Together with its variant "Basarwa," "Abathwa" occurs in languages as far afield as Cameroon, Tanzania and the southern African subcontinent. It describes people who are linguistically and culturally distinct from their pastoralist or mixed farming neighbours (Wilmsen 1989; Woodburn 1997). The term is understood to mean different things in a variety of cultural contexts: while generally indicating marginality across its range of use, thus acting as a term of rejection, discrimination and class differentiation, "Abathwa" can also indicate reverence and rank. In the face of this, it is not possible to use the xenonym "Abathwa" in a manner that recuperates or elevates the image of the San.

Xhosa speakers of South Africa see the San as occupying a very peculiar place in their cultural cosmology. In the Xhosa worldview, the San have special healing powers and knowledge and powerful rainmaking magic (Prins 1996; Francis 2007), and were seen as mediators between nature and culture (Prins and Lewis 1992). In Nguni society, the San were thought of as having privileged contact with the natural world and the forces, spirits, energies and matter that inhabit it. In this frame, the San acted as healers and rainmakers or even as individuals adept at providing apotropaic charms. Evidence for this in Nguni society is to be found in ethnographic materials. Some sangoma healers have modelled their practice and healing rituals around San/Abathwa "simulacra" (see Prins 1996; Jolly 1986 1996), while others claim that the twasa ancestral sickness that afflicted them and through which they became a sangoma was known as "Ntau," a character who had stolen the knowledge of magic and medicine from the San and had brought it back to Nguni society (pers. comm., Gogo Mokete, ca. 2002). Other instances are of the thriving San herbal practices in the southern Kalahari which people from as far away as the Eastern Cape consult for herbal and apotropaic medicines (Ellis 2012). The expression "Abathwa," however, is not only used in this positive sense but also has a range of negative connotations: the Abathwa were people who had to be feared, especially in their retribution. Sometimes they were looked down upon and seen as lower on the social scale. Above all else, it is not possible to isolate a single dominant perception of the San by Nguni speakers: while some saw them as a nuisance, others revered them as owners of potentially powerful magic.

The San were at once revered, sometimes treated as equals, often feared and at other times held to be of lower standing. Nowhere is the last point more clearly articulated that in the dealings with and perception of the so-called Basarwa in Botswana. "Basarwa" is a name that is used exclusively with reference to the San of Botswana where it signifies an underclass of "cattle-less serfs" (Hitchcock and Holm 1985, 1993; Motzafi -Haller 1994). The term "Basarwa," thus, signi-fi es not only a particular livelihood strategy but also an actual class position. Key in this context is that "Basarwa" is a relational concept, not an allusion to an isolated and insulated ethnic group. As such, it has also been applied to "other" cultural groups such as the Bakgalagadi. Although "Basarwa" does not enjoy widespread use in academic circles, the concept has usefully introduced the class element into the discussion about the San.

The overriding problem with all the terminology mentioned thus far is that the great linguistic and cultural variation of the San people is being masked by the use of these 
"umbrella terms" or waste basket taxa..$^{v}$ San as a category encompasses at least 20 distinct linguistic groups that were historically spread over seven southern African countries (Suzman 2001). To avoid the homogenising effect of the terms discussed above, some theorists have suggested that as far as possible the self-referents or specific ethnonyms should be used (Wilmsen 1989). This would allow researchers and interlocutors to highlight the local, cultural, linguistic, ecological and political particularities of the specific group they are speaking about (Ellis 2012). It would also require that for each group that is studied, its specific history, etymology, politics and class position has to be examined.

\section{Ascription or self-referents: pinning down the " $\neq$ Khomani"}

There can be no doubt that self-referents highlight the national, linguistic and even ethnic particularities of a group. However, in at least the case of the $\neq$ Khomani San, something completely different seems to be happening. The unproblematic application of selfreferents can mask a range of social, political and economic factors. While calling the \# Khomani San by the name they use for themselves identifies them as tied to a particular region, the term " $\neq$ Khomani" actually has a pedigree that suggests otherwise. The history of the term " $\neq$ Khomani" in the recent past has very little to do with an ethnic identity that can be demonstrated. First, " $\neq$ Khomani" is a xenonym that has become commonly used in the interplay of social, economic and political processes that have been intricately tied to the land claims process (Crawhall 2003; Ellis 2010, 2012). The exact origin of the word " $\neq$ Khomani" is unclear. Raymond Dart and the linguists who produced the southern Kalahari ethnographies of the 1930 s all agree that it is a foreign word, as its etymology and meaning were unknown in $\mathrm{N} / \mathrm{u}$, the language spoken by the $\neq$ Khomani (Dart 1937). Self-referential ethnonyms, however, are integrally linked to the mother tongue of the groups it labels. Following this logic, the last few N/u speakers have been questioned for self-referential names, but the search has not produced any results (Brenzinger, pers. comm., March 17, 2014; Crawhall 1999; see also Güldemann 2014). The most productive enquiry into the origin and meaning of the expression $\neq$ Khomani has been undertaken by Güldemann. This section examines his work in greater detail.

Despite the fact that there are still a significant number of unresolved land claims, the South African government recently announced that it would initiate another round of restitution claims. Moreover, it indicated that the new round might even accommodate claims outside the purview of the Restitution of Land Rights Act 22 of 1994 which had regulated these claims to date, allowing for the submission of tribal and aboriginal claims. To date, however, no new policy has emerged and this announcement seems to have been part only of pre-election rhetoric. Furthermore, experience in the case of claims that have been settled has shown that a settlement does not necessarily resolve all issues, as real, effective change requires far more than the simple handing back of land. Instead, sustained input and support is required for the new (old) owners to use the land successfully. This included, first of all, financial commitment, agricultural extension, advocacy, skills transfer and community work. It also required, and possibly even more critically, the building of cohesion within the claimant group, and the creation of a shared vision and sense of place that are essential for the land reform venture to be successful. One manner of creating cohesion is the selection of a name to denote the group in whose name the land is being claimed. The manner in which this can take place is examined here on 
the basis of the $\neq$ Khomani San of the southern Kalahari in Northern Cape Province of South Africa. In fact, the land claim of the $\neq$ Khomani San was plagued from the outset with problems of group cohesion and one of the clearest lenses to view these is through an examination of the search for a name for the land claim entity.

The present day creation of the term " $\neq$ Khomani" took place in a specific web of institutions and processes that emerged around the land claim. The group formed itself within a particular institutional framework that was part of the land claim settlement, an institutional context that needed juristic persons, groups with defined membership and organisations with names and constitutions to act as rights-holders in the aftermath of the claim. In the years prior to the land claim, no organised group calling itself "the \#Khomani" had existed for a number of decades, and possibly the last time this appellation had been used was during the 1930s when Raymond Dart and his colleagues conducted ethnographic research in the region. In fact, the San in the southern Kalahari were not even seen as forming a single ethnic entity that could be captured by a common ethnonym. Examination of the term " $\neq$ Khomani" indicates that it emerged from an academic ascription. The earliest recorded use of the term is in a report dated to 1908 by the regional magistrate Herbst where he recorded that there were two groups of San people in the area, one of which he referred to as the "Gommanes." vi Herbst used the term "Gommanes" to distinguish between two groups which he describes as having distinct racial characteristics, one being lighter than the other. A few years later Dorothea Bleek used the term $\neq$ Khomani as clear ethnic referent for people she encountered in the Nossob River settlements. Based on linguistic analyses, Bleek grouped the San people of the southern Kalahari into two groups: the N//n, to the east of the town of Mier, and the $\neq$ Khomani to its west (Bleek 1942). Critically, Bleek's categories were not of an ethnic or cultural nature. Later linguistic research proposed that the term " $\neq$ Khomani" could possibly have been used by !Xo speakers, or could have had roots in N/Amani (the language of the Kruiper clan), to refer to $\mathrm{N} / \mathrm{u}$ speakers (Crawhall 2005). The initial evidence from the specific ethnographic context suggests that the assumed bushmen ethnonyms are not self-referents but rather have been interpreted by Europeans and other San groups as either racial epithets, xenonyms or even misconstrued as glottonyms. This raises the question: if $\neq$ Khomani is not in fact the self-referential term for the group in question, what then can we surmise from $\mathrm{N} / \mathrm{u}$, the language originally spoken by the $\neq$ Khomani?

A good place to start would be to find out the word for person/people in the native tongue, to follow the example of the word "Bantu" that is used in reference to certain groups in Africa. In the $\mathrm{N} / \mathrm{u}$ language the term for person/people is sa (pl. saasi) (Crawhall 1999). However, this leads to two major problems. First, there is no record of the term sa/saasi being used in the historical record since linguists and anthropologists began to engage with this group in the 1930s. In fact, academics chose the term $\neq$ Khomani and not the possible self-referential sa/saasi.vii Second, of the less than 12 individuals who still speak $\mathrm{N} / \mathrm{u}$, all speak different regional variants or have only a fragmentary knowledge of the language. Only some, and not all, of these N/u speakers identified "saasi" as an autonym (Güldemann 2014; Brenzinger personal communication). Güldemann's work suggests that the term "saasi" could rather be an exonym, composed of the stem "saa" and the suffix "si." "Saa" is the familiar Khoikhoi term that refers to non-pastoral foragers and "si" 
is the suffix that is added to loan words in the $\mathrm{N} / \mathrm{u}$ language. Güldemann concludes that the term "saasi" is an imported exonym that has been naturalised among some $\mathrm{N} / \mathrm{u}$ speakers. A third fact to note is that no active linguistic community exists for the $\mathrm{N} / \mathrm{u}$ language. Thus, there is no term that enjoys widespread use by those who descend from the original $\mathrm{N} / \mathrm{u}$ speaking group. Since we cannot consider the terms from the N/u language, let us briefly examine how the word " $\neq$ Khomani" has become the common selfreferent in the present context.

In the early 1930s Raymond Dart was made aware of the presence of what many thought were last remaining "pure Bushmen in the Union." After studying the southern Kalahari San at the Empire Exhibition in 1936, Dart and several colleagues mounted an expedition (some-times called the Wits expedition) to the southern Kalahari to conduct anatomical, linguistic and other ethnographic research among the " $\neq$ Khomani" and other bushmen ethnic groups. The ethnographic work done by the Wits expedition would be published in the journal Bantu Studies and later as a book (I refer to them as the 1930s ethnographies). This ethnographic work would form the basis of the historical data used in verification of the land claim lodged in 1995. Ethnographers pointed to the southern Kalahari as the probable former "home" of several ethno-linguistic communities of San people (DugganCronin 1942; Trail 1974; Crawhall 1999). Crawhall (pers. comm., March 2000) argues, however, that the "racial purity" in this region "was never what Europeans wanted it to be,"viii and that there was "intermarriage between Basters, Griquas, Namas, and children of European men" (Dart 1937, 176). The racial, ethnic and linguistic character of the region was hard enough to unravel at this time and certain concessions had to be made by Raymond Dart and Donald Baine to ensure that the ethnography would have an authentic ethnographic entity as its subject (see Ellis 2012 and Gordon 1999 for details). My point here is that the intervention by Donald Baine and the subsequent ethnographic work by Dart and company had an important impact on the selection of a self-referent in the claims process that I briefly map out below.

During this field trip into the southern Kalahari the dominant self-referent that was used by the majority of the San people encountered by the Wits expedition was $\neq$ Khomani. At least four other ethnonyms were used in the production of the 1930s ethnographies: /Auni, N/amani, Katthea (Vaalpens) and !Xo (Duggan-Cronin 1942; Trail 1974; Crawhall). However, the individuals who were classed into these additional ethnic categories were smaller in number than those identified as $\neq$ Khomani, and the ethnonyms were given a reduced significance in the presentation of the data in the pages of Bantu Studies in which the research was presented. This assumed numerical superiority would influence the choice of ethnonym nearly sixty years later. Individuals researching the land claim in the 1990 os who had access to Dart's data would note Dart's ascription of numerical superiority and extrapolate into the present. Thus we fi nd that, early on in the claim process, a variety of these language-names were applied as assumed ethnic labels. Ethnonymic terms such as N/amani, /Auni or $\neq$ Khomani echoed the scholarly work from the 1930s. In this manner, the process of asserting a group identity to serve the land claims process would see the emergence of $\neq$ Khomani as the dominant self-referent. As a result, the identity formation, the becoming of "the $\neq$ Khomani," is bound up in a complicated manner with the history of ethnographic encounters with the southern Kalahari San as well as with the land claim against the Kalahari Gemsbok National Park.

\section{https://repository.uwc.ac.za/}


Prior to the land claim, the "descendants" of the southern Kalahari San lived in various settlements in the Gordonia district. Most who would eventually form part of the land claims community did not speak of themselves as San, $\neq$ Khomani, bushman or in terms of membership to a first nation. At this point, most descendants of the southern Kalahari San lived and thought of themselves as colouredsix in terms of the South African racial classification. For some, their coloured-ness was a complete disavowal of their bushmanness. Here I can cite a story told by one of the leaders in the claims process, Ouma [grandmother, a term of address for an older woman] //Unnas Rooi (also known as Katrina Rooi and Katjie Rooi). Ouma //Unnas and her sisters were some of the last N/u speakers. Ouma //Unnas reminisced of how she and her husband, as coloureds, were not allowed to mingle with the "Boesmans" in the Kalahari Gemsbok National Park. In short, no actual group of people calling itself the $\neq$ Khomani San existed from the 1950 os until the claim process was set in motion during the 1990s. Again I reiterate that, essentially, no single unifying ethnic identity for the southern Kalahari San existed before the land claim. It was the land claim that advocated a single unifying identity by being framed in terms of "the $\neq$ Khomani San."

The original group of San claimants which initiated the claim, consisting mainly of members from the extended Kruiper family, was not the one which began to use the term " $\neq$ Khomani" to identify an ethnic group. At the beginning of the claims process in 1995, it had rather decided that the general geographic term, southern Kalahari San, would be used to describe the "entity" sub-mitting the claim. When working through the historical data and as more evidence was presented, the researchers working on the land claim were confronted with a barrage of terms applied to the San of the southern Kalahari. These terms were mostly from the work done by Dart and colleagues in the 1930s. In order to navigate through the morass of terms and signifiers used to "name" the claimant group, several simplifications were made by those driving the land claim, including nongovernmental organisations and government officials. The group was identified, first, by its regional origin (namely, the southern Kalahari) and, secondly, by its "ethnic" identity, thus Namasa and $\neq$ Khomani, terms that had gained credence through the 1930 s ethnographies. Certain institutional structures (such as Common Property Association and community trusts) had to be brought into being for restitution purposes; these, in turn, were linked to group formation. ${ }^{\mathrm{x}}$

As far as the application of self-referents is concerned, these have to be read historically as they gained currency in differing political and cultural settings. I have also argued above that the term " $\neq$ Khomani" is a putative term that has subsequently become one of the key self-referents. This gives rise to the curious conclusion that the term " $\neq$ Khomani" is both ascriptive and autonymic: it was both applied to the San of the southern Kalahari by outsiders and the people themselves have chosen it as the preferred term for themselves, albeit in very different historical and political settings. In the final analysis, what is read as an ethnonym is actually a legal entity that is brought to life largely to serve as the juristic person that owns the land: its official title is the $\neq$ Khomani San Common Property Association. However, this interesting aspect of the name " $\neq$ Khomani" is not the only puzzling aspect about self-referential terms in the southern Kalahari. 
The dilemma here is that many of the San people I met during my fieldwork used terms that others perceived as negative. Members of the $\neq$ Khomani San frequently used corruptions of academically and "politically correct" terms. Two terms drew my attention in particular, namely "Boesman" and "Sand." The San people of the southern Kalahari, for example, commonly refer to themselves as "Boesmans," regardless of the term's negative connotations. The word "San" is most frequently used in circumstances of power, like in meetings of the Southern African San Council or of the Kalahari Gemsbok National Park, or in meetings with "government" and in other "official" forums. Yet, it is a term that is quite rare in everyday conversation in the southern Kalahari. The origin and meaning of the term "San" was not well understood by members of the $\neq$ Khomani San group. One possible reason may be that the people have a rather limited Nama vocabulary so the word is not known to them. In addition, $\neq$ Khomani often confuse the term, saying that they are "sand mense" [people of the sand] (see also Tomaselli 2007, 39). The term "sand" is a reference by the locals to the sandy geology of the region, as one interlocutor explained: the people are linked to the land through the sand, with the sand suggesting the Kalahari, a point to which I will return a little later in the paper. This clearly demonstrates that the use of specific expressions can be foreign even to those that they supposedly describe. An entire academic debate concerning politically correct terminology seems lost on the San of the southern Kalahari: many of the $\neq$ Khomani take pride in saying that they are "Boesmans."

This contradiction demands some exploration: why would people choose a name or term that has been deemed offensive for themselves? An event that transpired during the course of my field-work can be telling in this regard. I was roused from my tent one morning in 2001 by Abraham, the right-hand man of Oom [literally uncle, the term of address for an older man] Dawid who wanted to see me about some apparently pressing matter. Dawid Kruiper, who has since passed away, was both the elected and the commonly accepted traditional leader of the $\neq$ Khomani San. In addition, Oom Dawid was one of the "authors" of the land claim and one of the lead characters in the sub-sequent events. Abraham and I set off towards the Skilpad [tortoise], the massive domed grass hut where San residents at Witdraai habitually gathered during the day. By the time we arrived, Oom Dawid and his sons, as well as his extended family, were seated on the dusty ground in a close-knit circle. Oom Dawid recounted that he had been contacted telephonically by someone (he was not specific as to who the caller had been, but I think it might have been a journalist) who wanted to know his thoughts about the pending closure and removal of the (in)famous Bushman diorama in the South African Museum in Cape Town. The diorama contained reproductions of body casts of Bushmen that had been made by James Drury in the early decades of the 2oth century. Oom Dawid questioned me about the motivation that might lie behind such a move, while the others listened attentively to our exchange. ${ }^{\mathrm{xi}}$

My response was in the form of a short speech about the dichotomy between nature/culture and human/animal which placed black bodies, and here I included Bushman bodies, in nature and thus in closer proximity to the animal world, while "European white" bodies were seen as located in culture and thus in civilisation (see Wessels 2010). Oom Dawid and the others seemed unconvinced by my argument that the exhibit was racist because it displayed Bushman bodies in a natural history museum. 
Everyone present immediately and jointly objected to my position: all insisted that nature was exactly where they wanted to be placed. They were not troubled about being categorised as potential animals; quite the opposite, they seemed more concerned that, if they were not thought of as being attached to nature, outsiders would no longer be interested in their culture, since they would now be tainted by civilisation. xii

The use of a terminology that reflects political correctness, or at least has non-sexist, nonracist underpinnings, was not a driving factor in the selection of a name by the $\neq$ Khomani. The academic critique of the hierarchical intersection between race and nature, and primitive and civilised, and its partial resolution through the use of less problematic terms, was wholly rejected by the people in question. The individuals gathered around the tree on that particular morning demanded to be known as part of nature: they were prepared to accept the labels that went with that. The images I conjured up as negative connotations rang true and authentic for them. The dichotomies I highlighted - of nature and culture, of bushmen and other - were actively constructed, nurtured, internalised and sought out. To the people around the tree, being tied to nature was a boon. These San wanted to show closeness to nature, whether this took the form of sand, trees, rocks, the stars, plant medicine or even practices linked to nature such as conservation. If it meant being closer to or sharing a kinship with animals, through food, knowledge of animal habits or simply reading animals and nature as texts, this was what the southern Kalahari San wanted to be known for. Some pushed their kinship with animals so far as to remark that, at their death, their remains should be left to the animals of the veldt to dispose of. I even heard one person refer to the fate of Jezebel, whose corpse was eaten by stray dogs, as what they would desire for themselves. xiii In their estimation, if their name reflected the landscape that they occupy as one in which they are in nature, then this was a desirable appellation. Such an affinity could potentially even be profitable as many tourists would pay to see humans who had maintained a close connection with the natural world. Vital to them was exactly the ontological distinction between humans who are embedded in nature and humans who live removed from the natural world: this is the human and cultural capital that they want to transfer to their children.

Thus it is no surprise that the concern with being embedded in nature should be raised repeatedly by several $\neq$ Khomani, both in interactions with each other as well as those with outsiders. A key aspect through which the $\neq$ Khomani wanted to guarantee their entitlement to resources, most critically the land, was their continued ability to seat themselves within nature. Just as it marked off an action space for them in distinction to outsiders who they see as citified, modernised and anti-nature, this embedded-ness also allowed some of the San to separate themselves from other $\neq$ Khomani whom they saw as westernised.

In this world of intimacy with nature, the individual cannot become a bushman merely by voluntaristic self-appellation. Rather, it is incumbent on him or her to show affinity with nature and the ability to not only to navigate, but also to seat oneself in nature. Dawid Kruiper would often characterise the need to seat oneself in a particular role as a resignation to a role or identity. One of his favourite sayings was, "as jy ' $n$ leier will wees, moet jy ' $n$ luier kan dra ..." [if you want to be a leader, you must be willing to wear a 
diaper], always followed with one of his naughty giggles. The Afrikaans words for "leader" and "diaper" are homophones. Dawid's play on words referred to his wearing of a loin cloth and the refusal by his rival for traditional leadership to don this garb. In the understanding of these $\neq$ Khomani San, a true San had to be a certain kind of "being" who does not shy away from markers that signify bushman-ness. In order to be thought of as an authentic San person, you must be willing to take on and retain the prescribed way of being a San or bushman. San who considered themselves traditional often described San they considered to be westernised as living outside their own ecology, since they had lost the ability to live in and with nature, and with the plants and animals found in their world. Traditional $\neq$ Khomani saw these simulacral images of what it means to be a bushman as critical for their successful engagement with tourists and other interested parties, as the latter relied on these images to identify them as authentic and real.

\section{Some closing remarks}

"Boesman" and "Bushman" are terms that highlight exactly the characteristics that a portion of the $\neq$ Khomani argued would allow the formation of a life-world that could form part of the economic development proposals for the San of the region. The term "San" carried no meaning for many of the San, and they had often only heard it used in situations of power. For these San, being in nature or of nature was an empowering state that suggested they might achieve the level of economic development that they sought. Thus, the maintenance of an identity and the retention of a way of life was an aspirational venture as much as it was a search for authenticity.

On this basis, I conclude that the process of naming and the political or representational impact this might have were not simply a one-sided affair: naming does not simply stem from academic endeavours. Many of the $\neq$ Khomani San are in fact actively engaged in a process of creating an identity for themselves and shaping the meaning of the name they claim for themselves. This suggests that many of these individuals are well aware of how they have been represented (the authenticity construct) and that they regularly engage with it, not only as a way of preserving their heritage but also as a means of making a living. As suggested by Comaroff and Comaroff $(2009,11)$, these San were "seen, and reciprocally were able to see themselves, as a named people with a traditional way of life."

I want to make a few last remarks on naming and how it fi ts into the main theoretical point about authenticity. The last few decades have seen a variety of terms being "batted about," with some that had previously been discarded, such as bushman, now being salvaged. What has the search for new, less demeaning terms or names been about? At the least, the reshuffling and refinement of terms has been about the accurate description of a people. It has been about finding the names that people call themselves, or identifying such which, at least from our own attempts to be culturally, politically or otherwise sensitive, we think will fi $t$, or sit well, with all the parties concerned. Hence the search has been about accuracy in narrative, and finding an authentic name is at the centre of this. The search is for an authentic name that ties these displaced people to the land and through this suggests to them an accurate and truthful narrative of their San-ness.

This raises the question of the terms on which San people of the southern Kalahari are expected to participate in the new, post-1994 nation. The short answer is as bushmen. 
Any attempt by San people to live out a vision of San-ness that is radically different from the popularly recognised, simulacral San norm is treated with suspicion. Thus we see that non-governmental organisations treat San who want to engage in farming with suspicion: this is not what real bushmen are sup-posed to do. Any identities that are different from or sublated to that of the bushman are regarded as inauthentic: it is only the simulacral image of the Stone Age survivalist bushmen that make it into the imaginary of the western multicultural state. Two sets of play emerge and return to the name: the first is the rather politicised field of play that is the land claim and the second is the world of tourism and cultural commodities.

The first field of play, the land claim, can be one that is rather disempowering. It is the world of the English language, of government, of land claims, of legalese, of foreigners, of archives and proof. It is in this terrain that the tradisie Boesmans have tried to claim for themselves a portion of the developmental state. For the San living with Dawid Kruiper, the name "bushman" was a last ditch attempt to secure land from which they could exclude the westerse Boesmans who had already claimed the political terrain in institutions such as the South African San Council and the Khoisan consultative conference. This had raised the question of what would remain for them, the tradisie Boesmans. What remained for them was an identity that was marked out by the popontologies that outsiders held about bushmen. These pop-ontologies gave recognition to romantic ideas about the San, such as that bushmen are close to nature and are non-sexist and non-violent

But what about the accuracy of these these pop-ontologies of the noble savage? Here evidence from my ethnographic fieldwork may prove useful: Riekie Kruiper was brutally murdered with a rock and left to die under a tree on the farm Witdraai; Kabuis Kruiper found his wife sleeping with his friend (another bushman) and was beaten to death with a fencepost; while selling bushman curios on the side of the road, Dals jumped in front of a bus filled with tourists; Elsie Witbooi was murdered by her bushman boyfriend; Jacob Malgas, son of the bushman captain Abraham Malgas, was murdered by his wife; as well as high rates of alcohol abuse, domestic violence, teenage pregnancy, and allegations of paedophilia and pornography. Events such as these, that occurred regularly during my four year stay amongst the southern Kalahari San, indicate that the pop-ontology of the $\neq$ Khomani as noble savages is not a true reflection of their lives.

It may be clearer now that the term "San" belongs to a political terrain in which mainly people of colour and especially those known as Coloured are involved. "Boesman" belongs to the perceived pop-ontologies that many New Agers, tourists and practitioners of cultural salvage anthropology claim to find in the Kalahari. Lastly, with access to the political world closed off to Dawid Kuiper and those he looked after, the only way to ensure resources for themselves was to claim the term "Boesman."

\section{Acknowledgements}

I acknowledge the Centre for Humanities Research of the University of the Western Cape for the fellowship award that facilitated the writing of the present article. All credit for this article is attributed to the CHR at UWC. 


\section{Notes}

i In 2000, the Park became the Kgalagadi Transfrontier Park, effectively creating a jointly managed conservation area including Botswanan and South African territory. The San land claim and subsequently allocated rights only apply to the South African portion of the Park.

ii One example of how $\neq$ Khomani San were limited in how they could be themselves was the limitation placed on the types of materials they could use in the production of crafts and arts at the Sisen craft workshop. The Sisen craft workshop is the local art project in the Kalahari facilitated by NGO workers. The main aim is the production of crafts for sale to tourists. Facilitators would often limit the types of materials used to those "naturally" available, making plastic and artificial twin an anathema. Artworks or crafts made with materials other than approved materials were often censored (see Robins 2000, 2001; Ellis 2010, 2012).

iii When referring to bushmen as a simulacra, the lower case " $b$ " is used to show that it refers to a representation, not actual people. When Bushmen is spelled with a capital letter, it is taken to be either the actual words used in texts referenced or by interlocutors; alternatively, it is capitalised when it refers to a proper noun. My own practice is to use the term "San" when referring to people.

iv The fieldwork was conducted over a four year period between 1999 and 2003 in the various towns of the Mier municipality. I spent several months at any one time doing participant observation as well as participatory rapid appraisal with NGOs and extension workers.

$\mathrm{v}$ A waste basket taxon is a categorisation that enjoys some scientific credibility but that is simply a classification into which various other classes of object that do not fit are dumped. Two interesting examples of this are the categories "dinosaurs" and "fish," both of which are not species in the technical sense. Similarly, bushmen is a category that makes sense in lay circles but has very real sustained linguistic, historical or "cultural" credence.

vi Cape Archives, Cape Parliamentary Papers, Annexures to the votes and proceedings of the House of Parliament G-53: Magistrate Herbst, 1908, "Report on the Rietfontein area." vii It is interesting to note that one of the non-governmental organisations currently working with the San in the southern Kalahari chose the acronym SASI (South African San Institute), which echoes the self-referential term sa/sassi in the N/u language.

viii This quote was part of a conversation about the article by Raymond Dart (1937) (also see the following quote). I understood Europeans to mean both the farmers in the Kalahari in the 1930 s and the researchers and lobbyists who were engaged in bushmen research and advocacy in the region during the late 1930 .

ix The term "coloured" is not capitalised to show its sketchy legitimacy in the apartheid and post-apartheid political context.

$x$ For a further discussion of the process of group formation and selection of an ethnonym for the land claim, see Ellis $(2010,2012)$.

xi Note the ironic reversal here of the ethnographer being interviewed by the "Other."

xii For more information about the reasons for the closure and the debate that erupted, see Davison (1991, 1998) and Hendricks (2010).

xiii I am here reminded of an event during my fieldwork. I was outside my landlord's home at Rietfontein when I saw a vehicle strike a dog and kill it. The corpse lay there for two days, to be cannibalised by a pack of dogs on the second afternoon. The town has very few shops and, in my experience, none of them sells dog food. This raises the question of what dogs eat. In hunting packs, injured dogs are often attacked and eaten by the other members of the pack. So, the wish by some people to have their corpses laid out for dogs or wild animals to devour needs to be understood in a context where this occurrence is probably not unusual. 


\section{References}

Bleek, D.F. 1942. "Introduction.” In The Bushman Tribes of Southern Africa, by A.M. Duggan-Cronin. Kimberley: Alexander McGregor Memorial Museum.

Bredekamp, H.C. 1991. "Die Khoisan en vakterminologie na The Oxford History of South Africa: "n historiografiese dilemma." South African Historical Journal 25 (1): 61-76.

Comaroff, J.L., and J. Comaroff. 2009 Ethnicity, Inc. Chicago: University of Chicago Press.

Crawhall, N. 1999. "Reclaiming Rights, Resources and Identity: The Power of an Ancient San Language." In Voices, Values and Identities Symposium: Record of the Proceedings, 25-27 August 1998, edited by Y. Dladla, 57-71. Pretoria: South African National Parks.

Crawhall, N. 1999. "San and Khoe Rights, Identity and Language Survival in South Africa: Between Unity and Diversity.” In Essays on Nation-Building in Postapartheid South Africa. Cape Town: David Philip.

Crawhall, N. 2005. "Too Good to Leave Behind: The N/u Language and the $\neq$ Khomani People of Gordonia District." In Language and Identities in a Postcolony: Southern African Perspectives, edited by R. Finlayson and S. Slabbert. Frankfurt am Main: P. Lang.

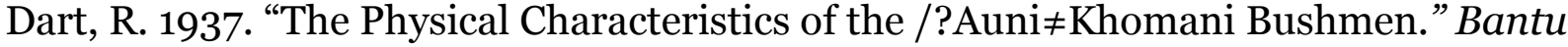
Studies 11 (3): 175-246.

Davison, P.J. 1991. "Material Culture, Context and Meaning: A Critical Investigation of Museum Practice, with Particular Reference to the South African Museum.” PhD diss., University of Cape Town.

Douglas, S. 1995. "The Human Isthmus: Dangerous Diluted Sewerage Poison: Recuperating 'Bushman' in the new South Africa.” Critical Arts 9 (2): 65-75.

Duggan-Cronin, A.M. 1942. The Bushman Tribes of Southern Africa. Kimberley: Alexander McGregor Memorial Museum.

Ellis, W. 2010. "The $\neq$ Khomani San Land Claim against the Kalahari Gemsbok National Park: Requiring and Acquiring Authenticity." In Land, Memory, Reconstruction, and Justice: Perspectives on Land Claims in South Africa, edited by C. Walker, A. Bohlin, R. Hall and T. Kepe, 181-197. Athens: Ohio University Press.

Ellis, W. 2012. "Genealogies and Narratives of San Authenticities: The $\neq$ Khomani San Land Claim in the Southern Kalahari." PhD diss., University of the Western Cape.

Ellis, W. 2014. "Simulacral, Genealogical, Auratic and Representational Failure: Bushman Authenticity as Methodological Collapse." Critical Arts 28 (3): 493-520.

Francis, M. 2007. "Explorations in Ethnicity and Social Change among Zulu-Speaking San Descendents of the Drakensberg Mountains, KwaZulu-Natal.” PhD diss., University of KwaZulu-Natal.

Gordon, R. 1999. “'Bain's Bushmen': Scenes at the Empires Exhibition, 1936.” In Africans on Stage: Studies in Ethnological Show Business, edited by B. Lindfors. Bloomington: Indiana University Press.

Gordon, R.J., and S. Sholto-Douglas. 2000. The Bushman Myth: The Making of a Namibian Underclass. 2nd ed. Boulder, CO: Westview Press.

Güldemann, T. 2014. "Towards Casting a Wider Net over the N//ng: Chances and Challenges of Archival Khoisan Resources.” Paper presented at The N//ng(n/uu) Conference, Cape Town, March 17.

Guenther, M. 1986. “San' or 'Bushmen.” In The Past and Future of !Kung Ethnography: Critical Reflections and Symbolic Perspectives. Essays in Honour of Lorna Marshall, edited by M. Biesele, R. Gordon and R. Lee. Hamburg: Helmut Buske Verlag.

Guenther, M. 1995. "Contested Images, Contexted Texts: The Politics of Representing the Bushmen of Southern Africa." Critical Arts 9 (2): 110-118.

Hegel, G.W.F. (1807) 1977. Phenomenology of Spirit. Translated by A.V. Miller.Oxford: 
Oxford University Press.

Hendricks, M. 2010. "Remaking / Xam Narratives in a Post-Apartheid South Africa." PhD diss., University of the Western Cape.

Hitchcock, R.K., and M. Biesele. 2000. "San, Khwe, Basarwa, or Bushmen? Terminology, Identity and Empowerment in Southern Africa." Khoisanpeoples.org.

khoisanpeoples.org/indepth/ind-identity.htm Hitchcock, R.K., M. Biesele, and R.B. Lee. 2003. "The San of Southern Africa: A Status Report, 2003." American Anthropological Association, Committee for Human Rights. http://www.aaanet.org/cmtes/cfhr/CfHR-Human-Rights-Documents.cfm

Hitchcock, R.K., and J.D. Holm. 1985. "Political Development among the Basarwa of Botswana." Cultural Survival Quarterly 9 (3): 7-11.

Hitchcock, R.K., and J.D. Holm. 1993. "Bureaucratic Domination of Hunter-Gatherer Societies: A Study of the San in Botswana.” Development and Change 24 (2): 305338.

Humphreys, A.B. 1985. “A Kaleidoscope of Values: Changing Perspectives on San Society." Kronos, no. 10: 58-66.

Jolly, P. 1986. "A First Generation Descendant of the Transkei San.” South African Archaeological Bulletin 41: 6-9.

Jolly, P. 1996. "Symbiotic Interaction between Black Farmers and South-Eastern San: Implications for Southern African Rock Art Studies, Ethnographic Analogy, and Hunter-Gatherer Cultural Identity." Current Anthropology 37 (2): 277-305.

Kohn, E. 2007. "How Dogs Dream: Amazonian Natures and the Politics of Transpecies Engagement." American Ethnologist 34 (1): 3-24.

Lee, R.B. 1976. "Introduction.” In Kalahari Hunter-Gatherers: Studies of the !Kung San and their Neighbors, edited by R.B. Lee and I. DeVore, 3-20. Cambridge: Harvard University Press.

Mbembe, A. 2001. On the Postcolony. Berkeley: University of California Press.

Morris, D.R. 1992. "South Africa: The Politics of Racial Terminology." Public Communication, no. 9: 111-121.

Motzafi-Haller, P. 1994. "When Bushmen are Known as Basarwa: Gender, Ethnicity, and Differentiation in Rural Botswana." American Ethnologist 21 (3): 539-563.

Nienaber, G.S. 1952. "Die woord 'Boesman." Theoria, no. 4: 36-40.

Nienaber, G.S. 1990. "Khoekhoen: spelling, vorme, betekenis.” African Studies 49 (2): 43-50.

Povinelli, E.A. 1998. "The Cunning of Recognition: Real Being and Aboriginal Recognition in Settler Australia." Australian Feminist Law Journal, no. 11: 3-27.

Povinelli, E.A. 2002. The Cunning of Recognition: Indigenous Alterities and the Making of Australian Multiculturalism. Durham, NC: Duke University Press.

Prins, F.E. 1996. "Praise to the Bushman Ancestors of the Water: The Integration of SanRelated Concepts in the Beliefs and Ritual of a Diviner's Training School in Tsolo, Eastern Cape.” In, edited by P. Skotnes, 211-224. Cape Town: University of Cape Town Press. Miscast: Negotiating the Presence of the Bushmen

Prins, F.E., and H. Lewis. 1992. "Bushmen as Mediators in Nguni Cosmology." Ethnology 31 (2): 133-147.

Rassool, C., and P. Hayes. 2002. "Science and the Spectacle: /Khanako's South Africa, 1936-1937." In Deep Histories: Gender and Colonialism in Southern Africa, edited by W. Woodward, P. Hayes and G. Minkley, 117-162. Amsterdam: Rodopi.

Robins, S. 2000. "Land Struggles and the Politics and Ethics of Representing 'Bushman' History and Identity." Kronos: Journal of Cape History, no. 26: 56-75.

Robins, S. 2001. "NGO's, 'Bushmen' and Double Vision: The $\neq$ Khomani San Land Claim and the Cultural Politics of 'Community' and 'Development' in the Kalahari." Journal of Southern African Studies 27 (4): 833-853.

Suzman, J. 2001. "An Introduction to the Regional Assessment of the Status of the San in

\section{https://repository.uwc.ac.za/}


Southern Africa.” Windhoek Report No.1. Windhoek: Legal Assistance Centre.

Tomaselli, K.G., ed. 2007. Writing in the San/d: Autoethnography among Indigenous

Southern Africans. Lanham, MD: Altamira.

Traill, A. 1974. A Complete Guide to the Koon: A Research Report on Linguistic

Fieldwork undertaken in Botswana and South West Africa. Johannesburg: University of the Witwatersrand Press.

Voss, A.E. 1990. "Die Bushie is dood: Long live the Bushie. Black South African Writers on the San." African Studies 49 (1): 59-69.

Wessels, M. 2010. Bushman Letters: Interpreting/Xam Narrative. Johannesburg: Wits University Press.

Wilmsen, E.N. 1989. Land Filled with Flies: A Political Economy of the Kalahari. Chicago: University of Chicago Press.

Wilmsen, E.N. 1996. "Decolonising the Mind: Steps Towards Cleansing the Bushman Stain from Southern African History." In Miscast: Negotiating the Presence of the Bushmen, edited by P. Skotnes, 185-190. Cape Town: University of Cape Town Press.

Woodburn, J. 1997. "Indigenous Discrimination: The Ideological Basis for Local Discrimination against Hunter-Gatherer Minorities in Sub-Saharan Africa." Ethnic and Racial Studies 20 (2): 345-361. 